\section{Canada's re-emerging division of powers and the unrealized force of reciprocal interjurisdictional immunity}

\section{Dwight Newman}

\section{Introduction}

In recent decades, up to the middle of the first decade of the twenty-first century, Canadian division-of-powers jurisprudence seems to have been in a period of quiescence, with modern doctrine imposing few constraints on the federal government's implementation of national programs. The Supreme Court of Canada had shown a readiness to uphold federal legislation in previously unanticipated areas, such as in the substantial federal roles developed in economic and environmental regulation. In the process, federal powers like trade and commerce and criminal law grew beyond their prior bounds. The Court simultaneously spoke of its innovations as if they marked an era of so-called "cooperative" federalism.

In the last five years, however, division of powers constraints on the federal government have re-emerged. In 2007, the decision in Canadian Western Bank (released with a companion decision in Lafarge to the same effect) contained a surprise twist: for the first time, the Court explicitly affirmed the reciprocal application of interjurisdictional immunity (IJI) ${ }^{1}$ to protect the core of provincial works and undertakings from federal interference. ${ }^{2}$ Although the doctrine of IJI should be reciprocal, protecting provincial works from federal incursions by federal laws and federal works from incursions by provincial laws, Canadian courts have previously applied the doctrine in an asymmetrical fashion consistently in favour of federal laws. In the two Bell Canada cases, ${ }^{3}$ for example, federal jurisdiction over interprovincial telecommunications won out over provincial jurisdiction in relation to labour relations. The decisions in these two cases resulted in a situation where provincial labour standards are inapplicable to federally regulated telecommunications companies and other federally regulated industries. However, this traditional application of the IJI doctrine provides no explanation for why the core of provincial labour relations jurisdiction counts for nothing. The subsequent decision in Canadian Western Bank came with a stricter test for IJI, seemingly applying IJI only where one government "sterilizes" an entity regulated by the other. This strict test has been removed again in a recent pair of aeronautics cases in Québec that have applied a less strict test again, as explained further below. The implication of IJI applying more broadly again, along with the decision that it is available in favour of the provinces, is that provincial IJI claims may now have teeth. One example is present in the Insite case, in which the British Columbia Court of Appeal held in favour of a provincial IJI claim 
in the context of the Insite Clinic's claims to a limited immunity from federal criminal law. ${ }^{4}$ It is at least possible that the Supreme Court of Canada will affirm the result.

This development on IJI was not an isolated re-emergence of restrictions on the federal government. The first Supreme Court of Canada decision in many years to strike down federal legislation on division-of-powers grounds was the Court's heated and divided decision in the Assisted Human Reproduction Act Reference, which was released in late December 2010-a few days before Christmas, thereby evoking only limited media attention. ${ }^{5}$ This decision has already borne fruit, with a five-judge panel of the Alberta Court of Appeal following its reasoning on the criminal law power and holding unanimously in March 2011 that the federal government's proposed national securities legislation is unconstitutional because it does not fit within the pertinent federal powers over the criminal law or trade and commerce. ${ }^{6}$ These most recent developments follow a year and a bit after the Supreme Court of Canada's decision in which it re-read the line between intraprovincial and interprovincial works and undertakings and re-invigorated provincial labour jurisdiction in Consolidated Fastfrate. ${ }^{7}$ To do so, the majority in that case turned to the drafters' intent in 1867 and the text of the Constitution Act, 1867 in preference over a purposive "living tree" analysis. ${ }^{8}$

In the context of these developments, my argument is that some of these recent changes contain as yet undeveloped and unrealized potential for even stronger affirmations of provincial jurisdiction in division-of-powers jurisprudence. In particular, I argue that the affirmation of reciprocal IJI contains a latent paradox that could portend even more substantial re-readings of past doctrine. Commencing with a very brief reminder of the scope of the two doctrines, I will outline first the paradox that can arise if a case invokes both the doctrines of provincial IJI and federal paramountcy. I then argue that this paradox cannot be untangled through what the Court first attempted, namely, the juggling of the sequences in which these doctrines apply. Finally,
I will argue that adopting provincial IJI, as the Court clearly chose to do in Canadian Western Bank, must imply further changes to recent federalism doctrine, potentially including the reaffirmation of spheres of genuine provincial exclusivity or even provincial paramountcy.

\section{Provincial interjurisdictional immunity and its doctrinal paradoxes}

The IJI doctrine emerges from the reality that if there are matters that actually fall within the jurisdiction of one level of government, they must have a core that is immune from adverse effect by the other level of government. Canadian Western Bank first retreats from any broad description of this doctrine in light of worries about whether it is in accord with the "dominant tide" of allowing concurrency ${ }^{9}$ and confines the test for IJI by requiring that a party wishing to make use of this doctrine must prove a real impairment of the vital or essential parts of an undertaking. The decision in this case suggests a preference for applying IJI only in contexts where precedent for doing so already exists. ${ }^{10}$ The Court could have stopped there, but instead restates the doctrine within a broader theoretical framework and also notes, importantly, that "[i]n theory, the doctrine is reciprocal: it applies both to protect provincial heads of power and provincially regulated undertakings from federal encroachment, and to protect federal heads of power and federally regulated undertakings from provincial encroachment." 11

In some respects, the first paradox that arises from the Canadian Western Bank decision is the awkward result that longstanding provincial advocacy of provincial IJI claims appears to have achieved fulfillment only at the same moment that IJI ceased to have much impact. At the moment when the test for IJI is made more stringent, and the Court urges an avoidance of the doctrine, only then does it finally explicitly permit provinces to use the doctrine. However, the Court has since unravelled this paradox, and without any cost to provincial IJI. In recent months, it has once again recognized 
the ongoing relevance of IJI and has restated the test once again, now seemingly somewhere between the stringent test some might have seen in Canadian Western Bank and the looser standard of "affecting a vital part."12

However, there is another paradox in the recognition of provincial IJI that arises when one considers the doctrine alongside that of federal paramountcy. The doctrine of federal paramountcy as developed by the courts states that "where there is an inconsistency between validly enacted but overlapping provincial and federal legislation, the provincial legislation is inoperative to the extent of the inconsistency"13 and that inconsistency or conflict exists when there is an impossibility of dual compliance and/or a frustration of federal parliamentary intent. ${ }^{14}$ The possibility of establishing federal paramountcy by showing provincial frustration of federal purpose, as opposed to actual operational conflict, is implicitly narrowed in the recent Supreme Court of Canada analyses, in that the Court has overturned appellate judgments that applied this branch of the paramountcy test too broadly. ${ }^{15}$

When considering the doctrine of federal paramountcy, one could envision before the courts a situation where a provincial law would benefit from IJI against overlapping federal legislation, but where there is a simultaneous claim that the federal legislation is paramount to the extent of any inconsistency with the provincial legislation. In such an event, a paradoxical set of conclusions would emerge whereby the federal legislation is inapplicable to the provincially regulated matters but where the provincial regulation is itself inoperative to the extent of its inconsistency with the federal legislation.

The Insite case, in which the British Columbia Court of Appeal has explicitly found in favour of provincial IJI, barely avoids bringing this paradox to the fore. In this case, the provincial activity was held to amount to a delivery of health services, and the health clinic's activities thus received the protection of IJI without having been directly related to any specific provincial statutory requirements. Had the clinic's activities been under a more explicit provincial statutory mandate, the provincial legislative provisions would have been subjected to federal paramountcy to the extent of their inconsistency with the federal legislation.

\section{Doctrinal juggling and its failure to resolve the paradox}

The Court in Canadian Western Bank was of course aware of the necessary interactions between IJI and paramountcy. Indeed, the Court split over what strikes many as a rather peculiar sort of issue: in what order the courts should turn to the doctrine of IJI and the doctrine of paramountcy. The majority adopted the new position that the courts should prefer paramountcy over IJI where "a case can be resolved" in this manner. ${ }^{16}$ Both the separate opinion of Bastarache $\mathrm{J}^{17}$ and the writings of Peter $\operatorname{Hogg}^{18}$ are vociferous in their challenge to this approach on the grounds that it lacks basic logic. The logic of it, in part, is to see if courts can avoid the creation of new IJI precedents. However, regardless of the order in which the doctrines are applied, the paradox I have raised remains.

Robin Elliot hints that the majority's conceptualization of the order is flawed, but he does not draw out the full conclusions to which I have referred here, noting only that the majority's order "only makes sense if the doctrine of IJI is invoked against provincial legislation." ${ }^{19}$ If the federal government challenges the impact of provincial legislation against federally regulated undertakings, a federal paramountcy result may approximately substitute for a federal IJI protection. However, if reciprocal IJI is at play, the application of federal paramountcy and provincial IJI can lead to results that clash. The majority's reasoning for preferring paramountcy where there is conflict would falter in the context of that order prioritizing federal paramountcy over provincial IJI. At the same time, the supposed logic of reversing the order would similarly falter in that it does not respect all the requirements of federalism.

Juggling the order of application of doctrines in the way done in Canadian Western Bank may be pertinent to the particular context 
that the Court was considering in that case, but at a more general level it does not save the structure of doctrines to which that case leads from the paradox identified here. Given that the Court in Canadian Western Bank was aware of the necessary interactions between IJI and paramountcy, and nonetheless chose to adopt a new doctrine of provincial IJI, the Court must be taken, in my view, to have done so deliberately, regardless of possible consequences for the doctrine of paramountcy. It is to the resulting implication of possible areas of provincial paramountcy that I turn in the next and penultimate section.

\section{New recognitions of provincial exclusivity and provincial paramountcy}

John Furey has hinted that there is something wrong with the combination of provincial IJI and federal paramountcy, noting that "[i]t could be argued that valid federal legislation could never be held inapplicable to a subject matter which is at the 'core' of a provincial power, if the rules of our Constitution state that paramountcy is reserved to the federal Parliament in the event of conflict between valid provincial and federal legislation." ${ }^{20} \mathrm{He}$ uses the argument to challenge provincial IJI, which was still a possible conclusion after Canadian Western Bank's overall tightening of access to IJI. In the context of the clear reawakening of IJI in subsequent cases, ${ }^{21}$ I would argue that because valid legislation can be held inapplicable to provincial matters, Canadian Western Bank can then lead to the conclusion that the constitution cannot restrict paramountcy to the federal government but actually must recognize provincial paramountcy. ${ }^{22}$

We can restate this claim. To say that federal legislation is always paramount to provincial legislation in cases of conflicts between them is effectively to say that federal legislation can always touch the core of a provincial power. But the Court's recent jurisprudence has deliberately said that provincial powers can receive the protection of IJI. This statement of law is present no less than three times in the Canadian Western Bank judgment. ${ }^{23}$ The modern legal position on IJI, then, must lead to a new position of affirming areas of provincial paramountcy.

A claim of provincial paramountcy in some areas, while not the orthodox position of recent times by any means, is not unprecedented. ${ }^{24}$ As I have noted in my recent commentary on Assisted Human Reproduction Act Reference, ${ }^{25}$ although the concept is not discussed in the Supreme Court of Canada ruling, the Québec Court of Appeal referred to the possibility of health care as an area of provincial paramountcy. ${ }^{26}$ Although occasional passages in Supreme Court of Canada judgments have sometimes conveyed skepticism towards notions of provincial paramountcy, ${ }^{27}$ it has arguably been present implicitly in other contexts. For example, one might mention the Court's affirmation that hospital decisions regarding the health care delivered to those hospitalized and not criminally responsible (NCR) take priority over determinations by review boards operating under federal criminal law authority. ${ }^{28}$ Moreover, recognition of the exclusivity of provincial powers has resulted in what amounts to provincial paramountcy in some contexts. One example, now in statute but originally rooted in common law, is the long-standing availability of the regulated conduct doctrine as a defence against federal charges where a province's regulatory rules for an industry explain a company's otherwise federally criminal conduct. ${ }^{29}$

The recognition of the fact that IJI protects cores of provincial areas of exclusivity leads logically to the prospect of provincial areas of exclusivity also receiving paramountcy-based protection. The requirements of adjudicative consistency, combined with the force attaching to the recent decision to affirm provincial IJI, lead to the prospect of areas of provincial paramountcy.

Some will worry about this conclusion. Those who lean toward ever-expanding central power will see dangers to their ideologies. However, the development of areas of provincial paramountcy flows logically from the principle of federalism. It also, I would suggest, connects 
to other related principles that provide the values basis for the recent division-of-powers case law-notably that of subsidiarity, a principle that I have recently discussed at greater length elsewhere. ${ }^{30}$ In brief, there has been a strong reference in case law over the last decade to the value of subsidiarity, namely the principle that "law-making and implementation are often best achieved at a level of government that is not only effective, but also closest to the citizens affected and thus most responsive to their needs, to local distinctiveness, and to population diversity." 31 To affirm provincial paramountcy is to act in accordance with both general federalism principles and the corollary of the subsidiarity principle.

More significant than the ideology-based objections of those who believe in only a centralized version of so-called federalism, is the potential objection that a move to the development of provincial paramountcy introduces new tensions within the legal reasoning that has led to the very basis for this doctrinal development. Specifically, some of the reasoning in Canadian Western Bank that leads to the IJI test enunciated in that case refers to the doctrine as potentially "superfluous" because precise parliamentary language can make clear the implications of paramount federal legislation vis-à-vis overlapping provincial legislation. ${ }^{32}$ Thus, removing the solely federal character of paramountcy would remove an underlying premise of some of the Canadian Western Bank reasoning.

To these counterarguments I would answer that the restricted approach to IJI in Canadian Western Bank has been rendered less constrained by the Supreme Court's subsequent IJI decisions. ${ }^{33}$ The objection just stated was, in one sense, that Canadian Western Bank's narrow IJI test flows partly from the availability of federal paramountcy and that altering federal paramountcy would call into question the case more generally. But the Court has already modified the strict IJI test Canadian Western Bank enunciated. The looser IJI test to which the Court has now moved is not dependent on the availability of federal paramountcy, as both IJI and paramountcy are available as tools in appropriate contexts. Federal paramountcy need not always be available, and there are areas of both federal and provincial exclusive jurisdiction that must be respected within a properly working federalism. The necessary respect is best maintained through both IJI and paramountcy, both applying reciprocally in appropriate contexts.

\section{Conclusion}

The demands of adjudicative consistency are some of the most fundamental demands of legality. One set of doctrinal adjustments will often evoke a call for other doctrinal adjustments, and if inconsistencies arise without these latter adjustments, then the force of legality specifically buttresses the call. Canadian division of powers has, once again, become a dynamic area of constitutional law and, as evident from my argument concerning inconsistencies at this interim point, more is yet to come. Latent within the recent case law's cautious development, there is both room and reason for yet more significant affirmations of provincial jurisdiction, specifically in the reaffirmation of spheres of genuine provincial exclusivity or even provincial paramountcy.

\section{Notes:}

* Professor of Law, University of Saskatchewan.

1. Interjurisdictional immunity is the doctrine that says that one level of government's legislation is inapplicable to the extent that it would intrude on the core of the other level's head of power, particularly in relation to a work, thing, or undertaking under that head of power. For example, parts of provincial governments' legislation on financial matters may not apply in certain respects to banks insofar as allowing that application would intrude on the core of the federal power over banking.

2. Canadian Western Bankv Alberta, 2007 SCC22, [2007] 2 SCR 3 at paras 35, 67, 77; British Columbia (Attorney General v Lafarge Canada Inc, 2007 SCC 23, [2007] 2 SCR 86.

3. Commission du salaire minimum v Bell Telephone Co. of Canada, [1966] SCR 767 (Bell Canada \#1) and Bell Canada v Quebec (Commission de la santé et de la sécurité du travail, [1988] 1 SCR 749 (Bell Canada \#2). The doctrine as traditionally 
applied provides no explanation for why the core of provincial labour relations jurisdiction counts for nothing.

4. PHS Community Services Society $v$ Canada (Attorney General), 2010 BCCA 15, 314 DLR (4th) 209, rev'd 2008 BCSC 661, 293 DLR (4th) 392, leave to appeal to SCC granted, 33556 (June 24, 2010) [Insite]. The Supreme Court's hearing of the appeal occurred on May 12, 2011.

5. Reference re Assisted Human Reproduction Act, 2010 SCC 61, 327 DLR (4th) 257. I discuss that judgment at greater length in: Dwight Newman, "Changing Division of Powers Doctrine and the Emergent Principle of Subsidiarity" (2011) 74 Sask L Rev 21.

6. See Reference Re Securities Act (Canada), 2011 ABCA 77 at para 31, [2011] AJ No 228 (adopting the new formulation of the criminal law power in the Assisted Human Reproduction Act Reference, supra note 5). See also the more recent decision of the Québec Court of Appeal in Québec (Procureure générale) c Canada (Procureure générale) (Renvoi concernant la compétence du parlement du Canada en matière de valeurs mobilières), 2011 QCCA 591.

7. Consolidated Fastfrate Inc $v$ Western Canada Council of Teamsters, 2009 SCC 53, [2009] 3 SCR 407.

8. Ibid at paras 33-44. The "living tree" methods of constitutional interpretation specifically envision growth of the constitution in light of modern needs, to be effected through judicial interpretation of the constitution in an evolving form, and they have arguably been prevalent over the past fifty years. The use of the specific intent and text from 1867 has been less popular but has been revived in this case.

9. Canadian Western Bank, supra note 2 at para 37. The concept of concurrency here, of areas simultaneously subject to federal and provincial regulation, is closely related to the idea of matters having a "double aspect", such that the federal governments have jurisdiction from one aspect and provinces jurisdiction from another aspect, but both ultimately regulate the same matter, The same river will be subject to federal regulation based on certain federal powers and provincial regulation based on provincial powers (Friends of the Oldman River Society $v$ Canada (Minister of Transport), [1992] 1 SCR 3), and the point applies more generally with respect to various fields in which federal and provincial regulation are now intertwined.

10. Canadian Western Bank, ibid at paras 48-53.

11. Ibid at para 35 .
12. See Québec (Attorney General) v Lacombe, 2010 SCC 38, [2010] SCR 53 [Lacombe]. See especially ibid. at para 112. See also Québec (Attorney General) $v$ Canadian Owners and Pilots Association, 2010 SCC 39, [2010] 2 SCR 536 [COPA]. The "affecting a vital part" test, one will recall, had taken on its full form in Bell \#2, supra note 2, in the specific context of the Court trying to use IJI to avoid simultaneous application to federally regulated employers of federal and provincial workplace safety standards (both validly enacted from different aspects) and the employers then needing to examine each standard for conflict under the paramountcy rules. In the process, though, it stated a very loose test for IJI. Canadian Western Bank, supra note 2 , restated a very strict standard. Lacombe purports to find a middle path.

13. Rothmans, Benson \& Hedges Inc $v$ Saskatchewan, 2005 SCC 13 at para 11, [2005] 1 SCR 188.

14. Ibid at paras 11-14.

15. See $i b i d$, allowing the appeal from 2003 SKCA 93, 232 DLR (4th) 495. See also Canadian Western Bank, supra note 2 at paras 70-74.

16. Canadian Western Bank, supra note 2 at para 77.

17. Ibid at paras 112-14 (separate judgment of Bastarache J).

18. See e.g. Peter W Hogg, Constitutional Law of Canada, student ed (Toronto: Carswell, 2010) at $15-29$, note $124 \mathrm{a}$.

19. Robin Elliot, "Interjurisdictional Immunity after Canadian Western Bank and Lafarge Canada Inc.: The Supreme Court Muddies the Doctrinal Waters-Again" (2008) 43 Sup Ct L Rev (2d) 433 at 495 .

20. John G Furey, "Interjurisdictional Immunity: The Pendulum Has Swung" (2008) 42 Sup Ct L $\operatorname{Rev}(2 d) 597$ at 610.

21. See Lacombe, supra note 12; COPA, supra note 12.

22. In strict logical terms, I am using the denial of the consequence to challenge the conditional premise of the argument. In the old philosophers' saying (variably attributed to Fred Dretske, Gilbert Harman, or others), one man's modus ponens is another man's modus tollens.

23. Canadian Western Bank, supra note 2 at paras $35,67,77$.

24. The inestimable John Whyte raised this debate in previous academic literature. However, Whyte presented provincial paramountcy in only a very particularistic form that diverged from our usual understandings of paramountcy. He offered the argument at a time prior to the more recent judicial support albeit based on analysis of the constitution itself, and he proposed it in the con- 
text of elaborating greater federal powers against which provincial paramountcy could provide some protection. See: John D Whyte, "Constitutional Aspects of Economic Development Policy," in Richard Simeon, ed, Division of Powers and Public Policy (Toronto: University of Toronto Press, 1985) 29 at 44-57; John D Whyte, "Federal Powers Over the Economy: Finding New Jurisdictional Room" (1987) 13 Can Bus LJ 257 at 282, n 60, 294, note101.

25. See Newman, supra note 5.

26. See Renvoi fait par le gouvernement du Québec en vertu de la Loi sur les renvois à la Cour d'appel, $L R Q$, ch $R-23$, relativement à la constitutionnalité des articles 8 à 19, 40 à 53, 60, 61 et 68 de la Loi sur la procréation assistée, LC 2004 ch 2 (Dans l'affaire du), 2008 QCCA 1167 at para 89, 298 DLR (4th) 712 (stating that "[p]lus récemment, la Cour suprême du Canada confirme la prépondérance provinciale en matière de législation relative à la santé dans les arrêts Chaoullic. Québec (Procureur général) et Mazzei c. Colombie Britannique (Directeur des Adult Forensic Psychiatric Services)" [emphasis in original]).

27. See especially Québec (Attorney General) v Moses, 2010 SCC 17 at para 13, [2010] 1 SCR 557

(Binnie J questioning the opinion of LeBel and Deschamps JJ on the basis that it turns the James Bay Agreement into "a vehicle for provincial paramountcy").

28. Mazzei v British Columbia (Director of Adult Forensic Psychiatric Services), 2006 SCC 7, [2006] 1 SCR 326.

29. See e.g. Garland v Consumers' Gas Co., 2004 SCC 25 at para 76, [2004] 1 SCR 629.

30. See Newman, supra note 5.

31. 114957 Canada Ltée (Spraytech, Société d'arrosage) $v$ Hudson (Town), 2001 SCC 40 at para 3, [2001] 2 SCR 241.

32. Canadian Western Bank, supra note 2 at para 46.

33. Lacombe, supra note 3; COPA, supra note 3. 